\title{
A Pan-American Perspective: An Interview with Carlos Morton
}

\section{Andrew Gibb}

Carlos Morton's professional playwriting credits include the San Francisco Mime Troupe, the New York Shakespeare Festival, the Denver Center Theatre, La Compañía Nacional de México, the Puerto Rican Traveling Theatre, and the Arizona Theatre Company. Morton's most recent book is Children of the Sun: Scenes and Monologues For Latino Youth (2008, Players Press). In 2006-2007 he was named Distinguished Fulbright Lecturer to Poland. He is currently Professor of Theater at the University of California, Santa Barbara. This interview was conducted via email in May 2009, when Dr. Morton was in residence at the University of California Washington Center in Washington, D.C. ${ }^{1}$

You are the child of a military family, and grew up in many different places. How do you think this lack of a "homeland" (so to speak) has affected your writing about the Latina/o experience?

The nucleus of the family was always Latino. My father was born in Chicago of Mexican immigrants who arrived in 1917 and my mother was born in San Antonio, Texas of a Mexican/Cuban couple who met in Detroit in the 1920s. We spoke Spanish at home and English in the public arena, so the "homeland" was the family. I've come back to that in my writing. As a child we lived in Panama (five years) and Ecuador (one year) so you never forget that. Being a Latino has always been a factor: after I got married to Azalea Marín López and had our sons, we lived in Mexico City, San José de Costa Rica, and Poland. In the 1980s I wrote La Malinche about the relationship between Hernán Cortés and the woman who helped him conquer Mexico. In the 1990s I wrote Dreaming on a Sunday in the Alameda about Diego Rivera's mural in the Alameda Park in Mexico City. The Savior, which is the story of Archbishop Óscar Romero of El Salvador, was translated into Spanish and 
adapted by Teatro la Fragua of Honduras whose director, Jack Warner, S.J., studied at the Goodman School of Drama in Chicago. "Meso-America" has always been a part of my history. My wife is from the Itsmo de Tehuantepec, and we go there a lot to visit friends and family. We named our youngest son "Xuncu" which means "el más pequeño" in Zapotec. For me, growing up, it was either cold, hard Chicago where everything was white and black and laid out on a grid with State and Madison as the cardinal points of reference, or the warm humid Caribbean waters with monkeys in the trees and crabs on the land.

During the early years of the Chicano Movement, you were living in a lot of places (Chicago, New York, El Paso) that were a long way away from the strikes in the grape fields or the shows on the backs of farm trucks. How did this distance shape your perspective on the Movement and the art that came out of it?

Well, it made me see things from afar, so I could maintain a certain distance. For example, I personally witnessed the 1968 Democratic Convention and the subsequent riots and demonstrations. I was working on a camera crew for ABC's Peter Jennings and was tear-gassed in Lincoln Park. Afterwards, I was so upset I "turned on, tuned in, and dropped out" of society. Before that, I was trying to be very middle-class, wearing button-down collared shirts, penny loafers, and driving a British sports car. Growing up I lived in the outskirts of Chicago.

You spent some time in New York City in the mid-seventies. What was the Latina/o theatre scene like in New York at that time?

The Nuyorican Poets Cafe was an exciting place to be in the midseventies, a gathering place for writers, players and hustlers on the "Loisaida" or Lower East Side of Manhattan. It was in a rough neighborhood, so there was always a certain risk involved. I lived in Manhattan, working as a freelance writer who wrote a number of articles about the Nuyorican theatre movement (a combination of New York and Puerto Rican) for local newspapers and national journals like Nuestro, the Latin American Theatre Review, and The Drama Review. Miguel Piñero, author of the prizewinning play Short Eyes, and Miguel Algarín, a Rutgers University Professor, started the cafe. One night Miguel Algarín told me the strange-looking old white guy standing at the bar was William Burroughs, the legendary writer of Naked Lunch. I really admired his writing and so I went up to him and introduced myself. It 
was very loud, people talking, music playing, and I said, "I've always wanted to meet you Mr. Burroughs, my name is Carlos Morton." Burroughs turned to me with a surprised look and exclaimed: "Carlos MORPHINE?" At least that's what he "heard."

Another time I got into an argument with a Nuyorican poet named Lucky Cienfuegos who pulled a switchblade knife on me. I can't recall what we were arguing about, probably poetry. To which I replied, "You win the argument, Lucky." One night I read from a play I was writing, Pancho Diablo, about a Chicano devil who quits his job in hell and moves to Houston (the play was produced at the Public Theater in 1987). No one was listening, it was late and loud and people were drunk — as was the reader - so I just gave up in disgust and threw the one-hundred-page script up in the air...it all fluttered down like a ticker tape parade on Fifth Avenue. I got the biggest applause of the night; people like Chicana writer Ana Castillo still recall it. ${ }^{2}$

Many Latina/o theatre artists cite a performance of El Teatro Campesino as their first introduction to the power of Latina/o theatre. What was your first Teatro Campesino show, and what effect did it have on you and your writing.

I always say it was an Antonin Artaud moment, as in the "Theatre as Plague," because it infected me and made me want to "join the circus." "3 ETC was doing an early version of Corridos. I felt an overwhelming desire to create new works of art that spoke to the Chicano people. Another big difference was that it was a theatre of commitment whose goal was to educate as well as entertain; something that I was looking for during the 1960 s as opposed to the sterile, flashy theatrefor-profit that promoted the ego and individualism versus the collective.

Many early Chicana/o theatre artists relied heavily upon improvisation and collective creation. But your work tends to follow a more traditional model of individual playwriting. Why do you think you were more attracted to that model?

Ironically, I never really worked with a collective until I worked with the San Francisco Mime Troupe from 1979-81. I took a couple of classes with El Teatro Campesino during the summer of 1974, but I never really fit in. I guess I feel more working by myself. On the other hand, my first experience at playwriting was when I took improv classes at The Second City in Chicago in 1967 and learned that the actor could write. 
You attended El Quinto Festival de los Teatros in Mexico City in 1974. What did you see there that shaped your work?

Different kinds of "theatre for the people," from the silly to the sublime, from magical realism to myth-based work to something approaching socialist realism. I also got to compare and contrast the difference in styles, language, etc., between the Chicano theatre groups heavily influenced by El Teatro Campesino and the more radical Latin American theatre groups like La Candelaria of Columbia, Los Mascarones of Mexico, and others. We also got to hear debates between Luís Valdez, Augusto Boal, and Enrique Buenaventura who criticized El Teatro Campesino for being too "spiritual and myth-based" as opposed to the more realistic approaches of the South American troupes.

You received graduate training at the University of California, San Diego. How did that institution nurture your work? What other companies or artists have provided you with mentorship over the course of your career?

Graduate training was a tremendous boost for my career. I received what to me was a generous San Diego Fellowship (1976-79) that allowed me, at the age of 29 , time to read, write, and create in an exciting laboratory setting (previously, I had been making a living as a cabdriver in Chicago and New York City). After graduating from UCSD I worked for the San Francisco Mime Troupe where I learned the meaning of humility. By that I mean submerging your ego for the good of the collective. I not only wrote plays, but learned to do publicity, outreach, organizing, driving a van, babysitting, and dishwashing! In the 1980s I worked on The Many Deaths of Danny Rosales at the Bilingual Foundation of the Arts and learned from Carmen Zapata. In 1986 Danny Rosales won the Latino playwriting prize at the New York Shakespeare Festival and I got to meet Joseph Papp and was given a staged reading at the Public Theater directed by Marvin Feliz Camillo, who had directed Short Eyes in 1974. The following year the Festival Latino directed by Oscar Ciccone and Cecilia Vega staged my musical Pancho Diablo.

And in 1988 Jorge Huerta directed El Jardin at Miriam Colón's Puerto Rican Traveling Theatre in New York City. These were all great learning experiences for me.

Since finishing your doctoral work at the University of Texas, you have been continuously employed in academia. What are the advantages of such work for a playwright? 
The university can be a nurturing laboratory to do new work. Not only your own, but also student work. I've had brilliant students like Edgar Poma and Rickerby Hinds who I feel proud of having nurtured. ${ }^{4}$

For several years you were the Director of the Center for Chicano Studies at the University of California, Santa Barbara. What do you see as the role of such organizations with respect to Latina/o art?

Centers like the now Chicano Studies Institute at UCSB (Carl Gutiérrez-Jones, Director), the UCLA Chicano Studies Research Center (Chon Noriega), the Hispanic Research Center at ASU (Gary Keller), the Institute for Latino Studies at Notre Dame (Gilberto Cárdenas) and the Center for Mexican-American Studies at UT Austin (José Limón) are all important incubators of Latino art, theatre, and literature. Centers support artists by funding new works, something that the federal and state governments are doing less and less of. If you go to Europe or Mexico and see how governments fund the arts, you see the difference it can make for society in general.

You have spoken of being a privileged member of the "Chicano Renaissance" of the sixties and seventies. Is that era over now? If so, what has replaced it?

I and others who lived in that era were lucky to be a part of the tide that washed over Latino society. I felt like I was riding a wave and I was on the cusp so to speak. Well, the wave broke and subsided somewhat. I don't see the same sense of urgency born out of despair that we had, but new waves are coming into America all the time. Look at the Dominican phenomenon as exemplified by the writer Junot Díaz, winner of the Pulitzer Prize for his novel The Brief Wondrous Life of Oscar Wao. And just recently my wife and I saw In the Heights on Broadway, which won all kinds of prizes for Best Musical. These are small groups of Latinos making a significant contribution to American culture.

The first significant international success for your work came in Mexico, where your plays have been translated and performed for some time now. In general, how have Latina/o arts been received in Mexico?

The Mexican government and intellectuals in general have always had a patronizing attitude towards Chicanos - look at Octavio Paz's El laberinto de la soledad and his first chapter on the Pachuco who he called "the extreme to which the Mexican can go." I've encountered Mexican academics who didn't even know who United Farm Workers founder César 
Chávez was, who thought a community center in Riverside, California was named after the Mexican boxer Julio César Chávez (true story). But some artists have come over to our side and lived and learned so there is progress being made. One of the most satisfying experiences I've had was the staging of Rancho Hollywood by Iona Weisberg in Mexico City at El Teatro Galeón in 1996. It's harder for Mexican Americans to go and live in Mexico because of the economics, and rare is the artist that can straddle both societies. I was fortunate in that as a child we lived in Panama, Ecuador and Mexico, so I was able to form a Pan-American sensibility.

In recent years, your work and that of other Latina/o playwrights has been receiving a good deal of attention from academics and cultural institutions in Europe. Having spent a year in Poland as a Fulbright Lecturer teaching about Latina/o theatre (among other things) what are your thoughts on the reasons behind this new interest?

It is fascinating how much interest there is not only in Latina/o theatre but also Chicano literature in general. When I arrived in Poland there were one or two researchers doing Latino Lit, now there are five or six and growing. A German scholar translated my play El Jardin 30 years ago, though I have no record that they ever produced the play. The same play was translated into Polish in 2007 by Kasia Bondaruk and next year (2010) Gabriella Varro is scheduled to translate El Jardin into Hungarian where it will be produced as part of a festival of Hungarian plays. Students in Belgium, Spain, and Austria have written their theses on my work. We are part of the American Experience and becoming more and more visible. The popularity and translations into other languages of women writers like Sandra Cisneros, Ana Castillo, and Denise Chávez also accelerated this trend.

In the last few decades, Latina/o playwrights have had increasing success in the mainstream U.S. theatre. How do you explain this trend? What effect do you think mainstreaming has on the traditional political messages of Latina/o theatre?

In general theatre is a more egalitarian art form than say, television, which is probably the most conservative medium there is. My feeling is that after the initial "affirmative action" period of regional theatres using Latinos, Blacks, and Asian Americans to get grants from the Ford and Rockefeller Foundations, etc., they saw that different audiences were attracted to this kind of theatre, and they recognized the demographic picture and realized 
that the blue-haired ladies weren't going to be attending performances in their wheelchairs and they had to get new blood in. Also the quality of the plays and performers improved: I'm talking about world-class artists like Guillermo Gómez Peña (love him or hate him), Luis Alfaro, Cherríe Moraga, Josefina Lopez, Octavio Solis, and of course Culture Clash who have fine-tuned their sketch comedy into an amazing art form. You have to give these groups credit for having raised the bar. If you have high quality performers they attract audiences and that makes the box office happy. And middle-class Latino audiences are coming to see the performances. And in the case of smash hits like In the Heights and the new bilingual West Side Story we can see that Latino sells on the Great "Brown" Way. As far as the political messages, they're in the subtext, but they're not as strident as before.

What effect (if any) do you think the recent economic downturn will have on the production of Latina/o theatre?

I don't think it will affect us that much because we've always had to do a lot with so little! As I travel through the country, from East Coast to West Coast, I see thriving community and professional theatres catering to the Latino and larger audience. Groups like Repertorio Español in New York, GALA Hispanic Theatre and Teatro de la Luna in D.C., Teatro Aguijón in Chicago, Borderlands Theater in Tucson, Teatro Dallas, Teatro Nuevo México in Albuquerque, El Teatro Campesino in California, the Latino Theater Company and Culture Clash (both based out of the New Los Angeles Theater Center), BOFLTE (Breath of Fire Latina Theater Ensemble) in Santa Ana, Teatro Visión is San José, and the Miracle Theatre Group in Portland, Oregon. I rest my case.

\section{Notes}

This interview grew out of conversations that took place at the Latin Writers Festival at Miami University in March 2009, a conference organized by Professor Eric Goodman (Department of English) and funded in part by the Miami University Department of Theatre (Dr. Elizabeth Reitz Mullenix, Chair). The author would like to thank Dr. Jorge Huerta (University of California, San Diego) and Dr. Ann Elizabeth Armstrong (Miami University) for their editorial advice, and to extend a special note of gratitude to Dr. Jody Enders (University of California, Santa Barbara) for the example of editorial excellence that she provided during her time at the helm of Theatre Survey.

2 The interviewee's memories of the Nuyorican Poets Cafe were originally shared with author Robin Hemley (http://robinhemley.com/). Mr. Hemley has graciously agreed to allow their publication here.

\footnotetext{
3 The reference here is to the first chapter of Artaud's The Theatre and Its Double.
} 
4 Jorge Huerta credits Poma's 1981 Reunion as "what appears to have been the first produced play centered on a Chicano gay male" (Chicano Drama: Performance, Society and Myth [Cambridge: Cambridge University Press, 2000] 159). The play originated as a class project for Carlos Morton's course at the University of California, Berkeley in 1980. Rickerby Hinds is currently an Associate Professor of Playwriting in the Department of Theatre at the University of California, Riverside.

5 Original Spanish: "uno de los extremos a que puede llegar el mexicano" (El laberinto de la soledad y otras obras, Penguin ediciones, [New York: Penguin Books, 1997] 35). 